\title{
Mengasah Dampak Penggiring (Nurturant Effect) Nilai Karakter Tanggung Jawab Melalui Integrasi Nilai-Nilai Keislaman dalam Pembelajaran Matematika
}

\author{
Nazliati ${ }^{1}$, Muhammad Reza \\ ${ }^{1}$ Institut Agama Islam Negeri Langsa \\ ${ }^{1}$ nazliati@iainlangsa.ac.id
}

\begin{tabular}{l}
\hline \hline Article Info \\
\hline Article history: \\
Received Oct $21^{\text {th }} 2021$ \\
Revised Nov $17^{\text {th }} 2021$ \\
Accepted Nov $23^{\text {th }} 2021$ \\
\hline
\end{tabular}

\section{Keywords:}

Nurturant Effects;

Value of Responsibility

Character;

Integration of Islamic

Values;

Math Learning

\section{Kata Kunci:}

Nurturant Effect;

Nilai Karakter Tanggung

Jawab;

Integrasi Nilai

Keislaman;

Pembelajaran

Matematika.

\section{Abstract}

The purpose of this study was to hone the nurturant effect of the value of the character of responsibility on students by integrating Islamic values in mathematics learning. This research is an experimental study using observations and interviews with 5 students of class VIII2 and teachers of SMPN 5 Langsa. Based on the results of the study, it was found that there was a development of the value of the character of responsibility which included a sense of responsibility in completing the tasks that had been given, awareness in helping to solve problems in the group, discipline, and awareness of serving punishment if violating the rules.

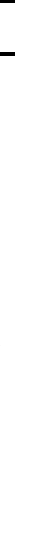




\section{PENDAHULUAN}

Pendidikan merupakan salah satu aspek terpenting seiring dengan perkembangan ilmu pengetahuan dan teknologi dunia. Pendidikan harus mampu mengakomodasi kebutuhan setiap peserta didik agar mampu menghadapi tuntutan zaman. Tujuan pendidikan (Pasal 3 UU No. 20 tahun 2003) adalah untuk mengembangkan potensi peserta didik agar menjadi manusia yang beriman dan bertakwa kepada Tuhan Yang Maha Esa, berakhlak mulia, sehat, berilmu, cakap, kreatif, mandiri, dan menjadi warga negara yang demokrasi serta bertanggung jawab.

Untuk mewujudkan tujuan pendidikan tersebut diperlukan sebuah pedoman salah satunya kurikulum. Kurikulum pembelajaran di Indonesia telah beberapa kali mengalami perubahan. Kurikulum 2013 merupakan kurikulum yang dirancang dengan mengedepankan pengembangan kompetensi sikap spiritual dan sosial yang diselaraskan dengan pengembangan kompetensi pengetahuan/intelek. Orientasi Kurikulum 2013 dapat dilihat dari peningkatan dan keseimbangan antara kompetensi sikap (attitude), keterampilan (skills), dan pengetahuan (knowledge), metode pendidikan yang diterapkan tidak lagi berupa pengajaran demi kelulusan ujian (teaching to the test) akan tetapi pendidikan lebih menyeluruh dengan memperhatikan kemampuan sosial, watak, budi pekerti, kecintaan budaya bangsa, dan sebagainya (Amaliah, 2017).

Konsep dan strategi pembelajaran dalam Kurikulum 2013 dalam Permendikbud 81A tahun 2013, mencakup dua proses pembelajaran, yaitu proses pembelajaran langsung (direct instructional) berupa kegiatan-kegiatan pembelajaran yang langsung dan eksplisit, penyampaian dan uraiannya langsung diarahkan oleh guru di depan kelas secara jelas yang bertujuan meningkatkan nilai kognitif dan psikomotor siswa. Sedangkan proses pembelajaran tidak langsung atau dampak pengiring (nurturant effect) lebih kepada penyampaian secara implisit yang dilakukan guru selama proses pembelajaran, cakupan nurturant effect sendiri berupa pengembangan nilai-nilai afektif siswa yang dilakukan guru, seperti pemberian motivasi, pengarahan untuk bersikap baik dan menghormati, penanaman nilai tanggung jawab dan lain-lain. Nurturant effect berasal dari dua suku kata, yaitu nurturant dan effect. 
Nurturant dalam kamus besar bahasa Inggris berasal dari kata nurse "pengasuh atau perawat" dan effect yang berarti "dampak" (Shadly \& Echols, 1975). Joice dan Weel (2013) mendefinisikan nurturant effect sebagai hasil yang ditimbulkan dalam sebuah pembelajaran yang disampaikan secara tidak langsung (indirect teaching) yang menekankan pada tercapainya ranah tujuan pembelajaran afektif berupa perasaan, emosi, atau tingkat penerimaan terhadap objek. Samani \& Hariyanto (2013) mengartikan nurturan effect sebagai dampak yang muncul dari pengalaman siswa yang diperoleh melalui lingkungan belajar yang disampaikan oleh seorang guru melalui bimbingan dan arahan secara tidak langsung yang bernilai kepada pengembangan nilai afektif siswa berupa, motivasi, terbuka dan demokratis, menghargai, menerima, serta kritis terhadap suatu persoalan.

Berdasarkan hal di atas dapat dipahami bahwa kurikulum 2013 menekankan keseimbangan pada ranah kognitif, afektif, dan psikomotor pada siswa. Sehingga untuk penerapannya sangat tergantung pada guru. Guru harus mampu mengintegrasikan tiap-tiap materi pembelajaran umum (Scientific) seperti matematika dengan materi pembelajaran khusus seperti agama dan kewarganegaraan dengan acuan terbentuknya pengetahuan dan terbinanya moral siswa demi perbaikan mutu pendidikan (Hamdayana, 2016).

Matematika adalah ilmu universal yang mendasari perkembangan ilmu pengetahuan dan teknologi modern, serta mempunyai peranan penting dalam perkembangan berpikir manusia. Matematika merupakan pelajaran yang menurut pola berpikir yang logis, rasional, kritis, dan sistematis (Asmarani \& Sholihah, 2017). Matematika juga merupakan pembelajaran yang sangat penting dipelajari oleh umat muslim, seperti yang dikemukakan oleh Abdussakir (2006) dalam bukunya yang berjudul Ketika Kyai Mengajar Matematika, sesungguhnya matematika itu memiliki hubungan yang sangat erat dengan tradisi spiritual umat Islam, akrab dengan al-Qur'an, dan tentunya matematika juga dapat dijadikan sebagai "jalan" menuju pencapaian manfaat-kebahagiaan baik di dunia maupun akhirat (Anggreni, 2019). 
Untuk meningkatkan hasil pembelajaran yang optimal dan sesuai dengan kurikulum 2013, pembelajaran matematika harus mengalami perubahan. Disamping pendidikannya diselaraskan dengan kemajuan teknologi, pendidikannya juga diharapkan dapat membangun nilai dan watak dari setiap siswa melalui nilai-nilai agama. Oleh karena itu diperlukan integrasi nilai-nilai yang terkandung dalam agama Islam dalam setiap pembelajarannya. Sehingga, selain dapat mempelajari matematika siswa juga dapat mempelajari keagungan Allah melalui pendekatan materi-materi matematika.

Adapun tantangan yang dihadapi guru yang masih menjadi masalah salah satunya adalah dalam merealisasi nilai tanggung jawab. Dalam proses pembelajaran banyak dari nilai tanggung jawab yang masih kurang mampu diaplikasikan, misalnya masih banyaknya siswa tidak menyelesaikan tugas rumah ataupun latihan di sekolah yang telah diberikan guru, tugas yang dikumpulkan merupakan hasil contekan atau salinan dari temannya tanpa memahami isi materi yang terkandung di dalam tugas tersebut, dalam hal ini sering terjadi khususnya dalam pembelajaran yang memerlukan pemahaman dan konsentrasi yang tinggi salah satunya pada pembelajaran matematika.

\section{METODE PENELITIAN}

Penelitian ini merupakan penelitian eksperimen dimana siswa diberikan perlakuan berupa pembelajaran matematika dengan mengaitkan nilai-nilai integrasi keislaman dalam pembelajaran matematika. Observasi dari awal pembelajaran sampai selesai dilakukan terhadap 5 siswa kelas $\mathrm{VIII}_{2}$ dengan fokus memperhatikan pada perubahan karakter yang terjadi selama proses pembelajaran. Kelima informan ini merupakan siswa yang bermasalah di kelasnya dimana siswa ini sering tidak mengumpulkan tugas rumahnya, tugas atau latihan yang dikumpulkan merupakan hasil salinan tugas atau latihan kawan sekelasnya, sering mengganggu kawan sekelasnya, kurangnya rasa hormat terhadap guru dan kawan sekelasnya serta sering melewati kelas. Wawancara dengan guru dilakukan untuk mendapatkan informasi tentang karakter siswa serta kendala yang 
dihadapi guru dalam mengintegrasikan nilai-nilai keislaman dalam pembelajaran matematika.

\section{HASIL PENELITIAN DAN PEMBAHASAN}

Penelitian ini merupakan penelitian eksperimen yang dimulakan dengan proses pembelajaran sebagai bentuk treatment dan kemudian dalam masa pembelajaran dilakukan pengamatan, berikut adalah tahapan yang dilakukan dalam penelitian:

\section{Tahap Pendahuluan}

Pembelajaran dimulai dengan mengecek kesiapan siswa dengan meminta siswa membaca doa sebelum pembelajaran dimulai, mengecek kehadiran siswa dengan memanggil nama setiap siswa di kelas. Pada tahap unsur-unsur nurturant effect mulai diasah dengan menegur siswa yang belum disiplin, dan memotivasi siswa untuk terus memperbaiki sikap terutama sikap tanggung jawab.

\section{Tahap Inti}

Pembelajaran pada tahap ini menggunakan metode pembelajaran discovery. Penggunaan metode ini dimaksudkan supaya siswa lebih kreatif dan terbiasa menemukan konsep serta mampu mengambil kesimpulan dari hasil pengamatan lingkungan sekitarnya. Pada tahap inilah integrasi nilai-nilai keislaman dalam pembelajaran matematika dilakukan. Siswa yang telah dibagi ke dalam 4 kelompok diminta untuk menunjukkan pola bilangan matematika melalui pengamatan lingkungan sekitar. Peneliti menuntut siswa untuk menemukan contoh pola bilangan, seperti urutan kelopak bunga mawar yang tersusun rapi membentuk pola bilangan tersendiri. Siswa diminta berdiskusi dalam kelompoknya untuk menentukan bentuk pola bilangan dari bunga mawar tersebut.

Integrasi nilai-nilai keislaman yang ditekankan adalah Allah sebaik-baik pencipta (QS: al- Furqan: 2), setiap ciptaan Allah seimbang, terstruktur dan terukur sesuai takarannya ((QS: al-Hijr:21), al-Qamar:49). Allah SWT menyatakan dalam al-Quran bahwa Ia telah menciptakan langit dan bumi serta segala sesuatu yang ada dalamnya sesuai dengan aturan, hukum, sistem, pola dan aturan-aturan lain dengan serapi-rapinya. 
Semua itu berjalan menurut hukum dan aturan yang bersifat konstan dan teliti yang menggambarkan secara jelas kebesaran dan kekuasaan Allah SWT.

Dalam proses diskusi, asisten peneliti melakukan pengamatan terhadap kelompok diskusi dengan melihat nilai karakter tanggung jawab. Relevansinya dengan kandungan al-Qur'an dengan nilai karakter tanggung jawab adalah fitrahnya suatu kehidupan, ketika kita melakukan sesuatu sesuai dengan ketentuan maka kita akan mendapatkan ganjaran yang sesuai juga. Ketika kita berbuat baik maka balasan kebaikan juga yang akan didapat.

\section{Tahap Penutup}

Pada tahap ini siswa diminta untuk mengambil kesimpulan dari aktivitas pengamatan dan diskusi yang telah dilakukan. Peneliti juga memaparkan hasil pengamatan dan mengulang kembali keterkaitan antara ayat-ayat al-Qur'an yang dibacakan sebelumnya dengan pentingnya penanaman karakter atau sikap.

Bedasarkan hasil pengamatan, informan sangat antusias dalam pembelajaran, hal ini terlihat dari keaktifan dalam kelompok, kekompakan tim, semangat menyelesaikan tugas, saling membantu, memberi penjelasan kepada kawan sekelompoknya jika ada arahan atau ada informasi tambahan serta tetap fokus mendengarkan penjelasannya.

Informan (RM) menyebutkan di awal pembelajaran sedikit membingungkan namun setelah melalui pembelajaran dengan menggunakan discovery learning materi pola bilangan lebih mudah dipahami dengan memperhatikan pola bilangan yang terdapat di lingkungan sekitar (GL). NB menyebutkan bahwa mendapat ilmu baru dari pembelajaran ini, selain dapat menemukan pola bilangan dalam matematika dengan memperhatikan ciptaan Allah juga menunjukkan kebenaran al-Qur'an.

Dalam proses pembelajaran, peneliti membagikan kartu berwarna kepada setiap ketua kelompok dan meminta ketua kelompok menjaga sampai pembelajaran berakhir. Hasil yang didapatkan informan dapat 
mengembalikan semua kartu dengan sempurna. Ini menunjukkan karakter tanggung jawab telah diaplikasikan.

Istilah karakter dihubungkan dan dipertukarkan dengan istilah etika, akhlak, dan atau nilai dan berkaitan dengan kekuatan moral, berkonotasi positif, bukan netral. Karakter menurut Kamus Besar Bahasa Indonesia (2013) merupakan sifat-sifat kejiwaan, akhlak atau budi pekerti yang membedakan seseorang dari yang lain. Elkin dan Sweet (dalam Fathurrohman dkk., 2013) menjelaskan pendidikan karakter dimaknai sebagai "Character education is the deliberate effort to help people understand, care about, and act upon core ethical values". Pendidikan karakter adalah usaha yang sungguh-sungguh untuk membantu seseorang memahami, peduli, dan bertindak berdasarkan nilai-nilai etika. Sedangkan menurut Thomas Lickona (2012), karakter berkaitan dengan konsep moral (moral knonwing), sikap moral (moral felling), dan perilaku moral (moral behavior). Berdasarkan ketiga komponen ini dapat dinyatakan bahwa karakter yang baik didukung oleh pengetahuan tentang kebaikan, keinginan untuk berbuat baik, dan melakukan perbuatan kebaikan. Berkaitan dengan hal ini dia juga mengemukakan: character education is the deliberate effort to help people understand, care about, and act upon core ethical values" (pendidikan karakter adalah usaha sengaja (sadar) untuk membantu manusia memahami, peduli tentang, dan melaksanakan nilai-nilai etika inti). Bahkan dalam buku Character Matters dia menyebutkan: character education is the deliberate effort to cultivate virtue-that is objectively good human qualities-that are good for the individual person and good for the whole society (pendidikan karakter adalah usaha sengaja (sadar) untuk mewujudkan kebajikan, yaitu kualitas kemanusiaan yang baik secara objektif, bukan hanya baik untuk individu perseorangan, tetapi juga baik untuk masyarakat secara keseluruhan) (Lickona, 2012).

Adapun nilai-nilai dalam pendidikan karakter yang ditanamkan dan dikembangkan kepada siswa (Permendiknas Nomor 23 tahun 2006) antara lain: 
Religius. Sikap dan perilaku yang patuh dalam melaksanakan ajaran agama yang dianutnya, toleran terhadap pelaksanaan ibadah agama lain, dan hidup rukun dengan pemeluk agama lain.

Jujur. Perilaku yang didasarkan pada upaya menjadikan dirinya sebagai orang yang selalu dapat dipercaya dalam perkataan, tindakan, dan pekerjaan.

Toleransi. Sikap dan tindakan yang menghargai perbedaan agama, suku, etnis, pendapat, sikap, dan tindakan orang lain yang berbeda dari dirinya.

Disiplin. Tindakan yang menunjukkan perilaku tertib dan patuh pada berbagai ketentuan dan peraturan.

Kerja Keras. Perilaku yang menunjukkan upaya sungguh-sungguh dalam mengatasi berbagai hambatan belajar dan tugas, serta menyelesaikan tugas dengan sebaik-baiknya.

Kreatif. Berpikir dan melakukan sesuatu untuk menghasilkan cara atau hasil baru dari sesuatu yang telah dimiliki.

Mandiri. Sikap dan perilaku yang tidak mudah tergantung pada orang lain dalam menyelesaikan tugas-tugas.

Demokratis. Cara berfikir, bersikap, dan bertindak yang menilai sama hak dan kewajiban dirinya dan orang lain.

Rasa Ingin Tahu. Sikap dan tindakan yang selalu berupaya untuk mengetahui lebih mendalam dan meluas dari sesuatu yang dipelajarinya, dilihat, dan didengar.

Semangat Kebangsaan. Cara berpikir, bertindak, dan berwawasan yang menempatkan kepentingan bangsa dan negara di atas kepentingan diri dan kelompoknya.

Cinta Tanah Air. Cara berfikir, bersikap, dan berbuat yang menunjukkan kesetiaan, kepedulian, dan penghargaan yang tinggi terhadap bahasa, lingkungan fisik, sosial, budaya, ekonomi, dan politik bangsa.

Menghargai Prestasi. Sikap dan tindakan yang mendorong dirinya untuk menghasilkan sesuatu yang berguna bagi masyarakat, dan mengakui, serta menghormati keberhasilan orang lain. 
Bersahabat/ Komunikatif. Tindakan yang memperlihatkan rasa senang berbicara, bergaul, dan bekerja sama dengan orang lain.

Cinta Damai. Sikap, perkataan, dan tindakan yang menyebabkan orang lain merasa senang dan aman atas kehadiran dirinya.

Gemar Membaca. Kebiasaan menyediakan waktu untuk membaca berbagai bacaan yang memberikan kebajikan bagi dirinya.

Peduli Lingkungan. Sikap dan tindakan yang selalu berupaya mencegah kerusakan pada lingkungan alam di sekitarnya, dan mengembangkan upaya-upaya untuk memperbaiki kerusakan alam yang sudah terjadi.

Peduli Sosial. Sikap dan tindakan yang selalu ingin memberi bantuan pada orang lain dan masyarakat yang membutuhkan.

Tanggung jawab. Sikap dan perilaku seseorang untuk melaksanakan tugas dan kewajibannya, yang seharusnya dia lakukan terhadap diri sendiri, masyarakat, lingkungan (alam, sosial dan budaya), negara dan Tuhan Yang Maha Esa.

Matematika merupakan salah satu mata pelajaran yang diajarkan di sekolah menengah yang bertujuan untuk mempersiapkan siswa agar sanggup menghadapi perubahan keadaan dan pola pikir dalam kehidupan dan dunia selalu berkembang. Kurikulum 2013 telah menuntun penerapan karakter dalam setiap pembelajaran. Dikotomi pengetahuan harus dihilangkan, sehingga setiap pembelajaran tidak kecuali matematika yang merupakan mata pelajaran umum juga diharuskan disisipkan unsur-unsur karakter di dalamnya salah satunya dengan menyisipkan nilai-nilai keislaman dalam pembelajarannya sehingga diharapkan melahirkan lulusan yang berkarakter, sopan santun dalam bersosialisasi serta mampu diterima di masyarakat.

\section{SIMPULAN}

Terjadinya peningkatan dan respon positif dari siswa selama mengikuti pembelajaran matematika. Siswa lebih merasakan nilai tanggung jawab, seperti ketertarikan siswa terhadap pembelajaran yang semakin meningkat dan munculnya nilai menerima, menanggapi, 
menghargai, mengatur diri, serta kesadaran menjalani hukuman jika melanggar peraturan.

\section{DAFTAR PUSTAKA}

Ahmadi, A. dkk. (2013). Psikologi Belajar. Jakarta: Rineka Cipta.

Anggreni, F. 2019. Integrasi Al-Quran pada Mata Pelajaran Matematika terhadap Kemampuan Siswa, At-tarbawi: Jurnal Pendidikan, Sosial, dan Kebudayaan, 6 (1): 3. Doi: 10.32505/tarbawi.v6i1.1029.

Arikunto, S. (2013). Dasar-Dasar Evaluasi Pendidikan (Edisi Revisi). Jakarta: Bumi Aksara.

Aunillah, N. (2011). Panduan Menerapkan Pendidikan Karakter di Sekolah. Yogyakarta: Laksana.

Azwar, S. (2012). Metodologi Penelitian Kualitatif. Yogyakarta: Pustaka Pelajar.

Boeree, G. (2013). Personality Theories.Yogjakarta: Prismasophie.

Daradjat. (2016). Ilmu Pendidikan Islam (Cet.III). Jakarta: Bumi Aksara.

Departemen Pendidikan dan Kebudayaan Nomor 66 Tahun 2013

tentang Standar Penilaian Pendidikan, Jakarta: Direktorat Jendral Manajemen Pendidikan Dasar dan Menengah.

Departemen Pendidikan dan Kebudayaan. (2013). Kamus Besar Bahasa Indonesia. Jakarta: Balai Pustaka.

Djamarah, Syaiful Bahri. (2013). Guru dan Anak dalam Interaksi Edukatif. Jakarta: PT Rineka Cipta.

Fazari, Z. (2018). Sikap Guru dan Pemahaman Menerapkan Nurturant Effect. Langsa: MTsS MIM Langsa.

Hamalik, O. (2011). Kurikulum dan Pembelajaran. Jakarta: Bumi Aksara. Joyce, Bruce dkk. (2012). Model Soft Teaching :Model-Model Pengajaran (Edisi Delapan), Penerjemah: Achmad Fawaid dan Ateilla Mirza, Yogyakarta: Pustaka Pelajar.

Kumalasari, Ade dkk. (2013). Kesulitan Belajar Matematika Siswa Ditinjau dari Segi Kemampuan Koneksi Matematika. Prosiding ISBN: 978-979-16353-9-4. 
Kuswiyanto, D. (2010). Skripsi Upaya Guru Pendidikan Agama Islam dalam Mengembangkan Ranah Afektif Peserta Didik di SMP Negeri 4 Purwanegara Banjarnegara. Yogjakarta: UIN Sunan Kalijaga.

Lickona, T. 2012. Character Matters: Persoalan Karakter. terj. Juma dkk. Jakarta: Bumi Aksara.

Lickona, T. 2012. Educating for Character: Mendidik untuk Membentuk Karakter, terj. Juma Wadu Wamaungu dan Editor Uyu Wahyuddin dan Suryani, Jakarta: Bumi Aksara.

Lubis, Saiful Akhyar. (2010). Profesi Keguruan. Medan: Perdana Mulya Sarana.

Mahmud. (2011). Pemikiran Pendidikan Islam. Bandung: Pustaka Setia.

Maji dkk. (2010). Pendidikan Karakter Perspektif Islam. Bandung: Remaja Rosda Karya.

Nahlawi. (2012). Pendidikan Islam di Rumah Sekolah dan Masyarakat (cet.III). Jakarta: Gema Insani Press.

Nurfuadi, Moh. Roqib. (2016). Kepribadian Guru. Puwekerto (Revisi): STAIN Press \& Grafindo Litera Media.

Nurkancana, W. (2002). Evaluasi ilmu pendidikan. Surabaya: Usaha Nasional.

Purwanto, N. (2000). Psikologi Pendidikan, Bandung: Remaja Rosdakarya.

Samani, Muchlas \& Hariyanto. (2012). Konsep dan Model Pendidikan Karakter. Bandung: PT Remaja Rosdakarya.

Sanjaya. (2016). Strategi Pembelajaran (Revisi-III). Berorientasi Standar Proses Pendidikan Pranada Group.

Sugiyono. (2013). Metode Penelitian Pendidikan Pendekatan Kuantitatif, Kualitatif, dan R\&D. Bandung: Alfabeta.

Suparlan. (2012). Menjadi Guru Efektif. Yogyakarta: Hikayat Publishing. Suryabrata, Samadi. (1982). Perkembangan Individu. Jakarta: Rajawali.

Sutarto dkk. (2017). Jurnal Dampak Pengiring Pembelajaran Pendekatan Saintikfik Untuk Pengembangan Sikap Spiritual dan Sosial Siswa. Yogyakarta: Cakrawala Pendidikan. 
Syukur, F. (2011). Sejarah Peradaban Islam. Semarang: PT. Pustaa Rizki Putra.

Trianto. (2009). Mendesain Model Pembelajaran Inovatif Progresif, Jakarta: Kencana Prenada Media Group.

Usman. (2002). Menjadi Guru Profesional. Bandung: Remaja Rosda Karya.

Zuriah, N. (2013). Pendidikan Moral dan Budi Pekerti dalam Perspektif Perubahan Menggagas Platform Pendidikan Budi Pekerti Secara Kontekstual dan Futuristik. Jakarta: PT Bumi Aksara. 